\title{
Learning to Be Employable or Being Employable to Learn: The Reciprocal Relation Between Perceived Employability and Work-Related Learning
}

Journal of Career Development

(C) Curators of the University of Missouri 2019 Article reuse guidelines: sagepub.com/journals-permissions DOI: $10.1177 / 089484531986743$ | journals.sagepub.com/home/jcd

(SAGE Ellen Houben', Nele De Cuyper', Eva Kyndt' ${ }^{2,3}$, and Anneleen Forrier ${ }^{4}$

\begin{abstract}
Learning to become employable is a catch phrase often used to highlight the importance of upskilling in today's knowledge-based labor market. Yet, evidence on the relationship between work-related learning and employability is limited and does not account for potential reciprocity. This is important though: if employability also promotes work-related learning, labor market segmentation could be enhanced. Accordingly, this study investigates the reciprocal relationship between (formal and informal) work-related learning and perceived (internal and external) employability. Hypotheses are based on the attribution-based theory of intrapersonal motivation, which has not yet figured in employability research. Structural equation modeling was performed on three-wave survey data of Belgian employees. The pattern of results showed a reciprocal, albeit weak, relationship between formal work-related learning and perceived internal employability. No other significant relationships were established. Hence, the relationship between work-related learning and perceived employability might not be as straightforward as generally assumed.
\end{abstract}

\section{Keywords}

perceived employability, work-related learning, structural equation modeling, attribution-based theory of intrapersonal motivation

Employability concerns an individual's chance to find new employment (Forrier \& Sels, 2003a), which is deemed critical against the background of increasing job insecurity and the knowledge economy (Brown, Hesketh, \& Wiliams, 2003). Practitioners (De Vries, Gründemann, \& Van Vuuren, 2001),

\footnotetext{
' Research Group for Occupational \& Organizational Psychology and Professional Learning, KU Leuven, Leuven, Belgium

${ }^{2}$ Department of Training and Education Sciences, Faculty of Social Sciences, University of Antwerp, Antwerp, Belgium

${ }^{3}$ Centre for the New Workforce, Swinburne University of Technology, Australia

${ }^{4}$ Department of Work and Organization Studies, Faculty of Economics and Business, KU Leuven, Leuven, Belgium
}

\section{Corresponding Author:}

Ellen Houben, Research Group for Occupational \& Organizational Psychology and Professional Learning, KU Leuven, Dekenstraat 2, Box 3725, 3000 Leuven, Belgium.

Email: ellen.houben@kuleuven.be 
policy makers (e.g., Organisation for Economic Co-operation and Development [OECD], 2016), and scholars (e.g., Fleischmann, Koster, \& Schippers, 2015) all highlight the critical role of work-related learning in promoting employability. The implicit assumption is that everyone can become employable through learning, and this is a matter of individual responsibility (Forrier, De Cuyper, \& Akkermans, 2018): Employees are seen as free agents, who should take control over career-related matters, such as work-related learning, whenever they would want or need to. This view is highly agentic, and it implies that employees' career decisions are fully dependent upon the individuals and their reality (Goller \& Harteis, 2017). Hence, the current study approaches employability using perceived employability, which concerns individuals' evaluations of their employment chances (De Cuyper \& De Witte, 2008).

Yet, this agentic view might only apply to those who perceive themselves as highly employable and not, or in any case far less, to those who perceive themselves as less employable (Forrier et al., 2018): In particular, less employable individuals may perceive many labor market boundaries. These perceptions may prevent them to exert their agency, or engage in work-related learning, as much as high-perceived employable workers do. This idea is central to the notion of bounded agency, which states that agency is dependent upon the interplay of dispositional and structural boundaries that individuals encounter (Desjardins \& Rubenson, 2009). Moreover, given that perceptions are the primary motive for action, perceived employability ensures the individuals' awareness of their employability, which might evoke reactions, such as the engagement (or disengagement) in work-related learning (Katz \& Kahn, 1978).

A reciprocal relationship between perceived employability and work-related learning would imply the risk of increasing polarization in the labor market: Those who perceive themselves as employable engage in work-related learning which then promotes their perception of being employable, and vice versa for those who perceive themselves as less employable. So far, reciprocity has not yet attracted much attention (Veld, Semeijn, \& Vuuren, 2015), and the relationship from perceived employability to learning has been suggested and demonstrated by Kyndt, Onghena, Smet, and Dochy (2014), yet only cross-sectionally.

Accordingly, our aim is to investigate reciprocity between work-related learning and perceived employability, while conceiving these concepts broadly. In particular, work-related learning is conceptualized using all formal and informal learning activities individuals undertake with regard to their career (Kyndt \& Baert, 2013). Formal work-related learning concerns the engagement in learning activities which contain a specific goal, context, support, and time frame (Colley, Hodkinson, \& Malcom, 2003). Informal work-related learning, on the contrary, entails all learning activities that emanate from daily work-related experiences involving personal sources (e.g., reflection, asking feedback, observing others) and environmental sources (e.g., reading books, surfing the web; Noe, Tews, \& Marand, 2013). Perceived employability is conceptualized as individuals' evaluations of their employment chances in both the internal (i.e., within the current organization) and external labor market (i.e., beyond the boundaries of the current organization; De Cuyper \& De Witte, 2008).

The aim was achieved using structural equation modeling on three-wave survey data of a diverse sample of Belgian employees in terms of participants' organizational type and demographic characteristics such as age, educational level, and gender. We placed this aim against the background of Weiner's (2000) attribution-based theory of intrapersonal motivation. This theory is, to the best of our knowledge, not yet introduced in employability literature but has particular appeal: It provides an explanation for how actions (e.g., work-related learning) and perceptions (e.g., perceived employability) are related, as it is guided by the idea that people act upon their own personal understanding of themselves and the context they are in (Weiner, 2000).

\section{Theoretical Framework}

Attributions involve perceptions of causality that individuals use to make sense of their environment (Weiner, 1976). Attribution theory is often used to predict why others behave in a certain manner and 
relatively seldom in relation to the self: This relates to differences between interpersonal (e.g., Nishii, Lepak, \& Schneider's, 2008, HR attributions) and intrapersonal theories of motivation. Although not a perfect one-to-one match, intrapersonal theories have particular resonance for the purpose of this study because they assume that individuals act upon their own perception.

In particular, the attribution-based theory of intrapersonal motivation (2000) is based on the idea that individuals base their own actions on their perceptions of the causality of previous successes and/or failures (Weiner, 2000). They act in order to continue success (and related positive events and feelings) and to discontinue failures (and related negative events and feelings; Weiner, 2000). Applied to the current study, employees might act to increase perceived employability, as it implies success: Perceived employability reflects success in the labor market and brings about positive feelings (e.g., occupational health and well-being; Vanhercke et al., 2015) and events (e.g., job transitions; Nelissen, Forrier, \& Verbruggen, 2017).

Attributions are often colored by hedonic biasing: Success, in comparison to failure, is more likely to be internally attributed (Weiner, 2000). If individuals believe that they have control over their successes themselves, they are likely to put in effort to stimulate or maintain them (Weiner, 2000). As such, these behaviors involve expectancies of success. This relates closely to expectancyvalue theory (Atkinson, 1957), as these successes motivate people to handle in terms of beneficial outcomes (Weiner, 1985). The implication for this study is that perceived employability is seen as a success, which individuals want to stimulate. They may do so by engaging in work-related learning: Work-related learning, in this sense, is seen as the effort that individuals make to stimulate this type of success.

With time, a cycle of reciprocal interactions might establish and the success-effort relation might become unconscious and habitual (Kelley \& Michela, 1980). This unconscious and habitual cycle of reciprocal interactions between perceived employability and work-related learning might establish quit early in an individual's career. Indeed, the idea that learning contributes to labor market chances is rooted in the importance that is attached to formal education: Students engage in education to prepare for the labor market. Furthermore, it is often stressed, and empirically supported, that the higher the students' educational degree, the more job opportunities they will receive (and perceive; European Commission, 2014). But also, governments (OECD, 2016) and organizations (De Vries et al., 2001) emphasize the need to learn in order to become employable. This reflects a norm which individuals might internalize quit easily (Weiner, 2000). Only when these implicit attributions are disconfirmed, individuals might consciously consider attributing differently, which may then change their behavior (Weiner, 1985).

Along those lines, people who perceive themselves as less employable might encounter more labor market barriers than those who perceive themselves as highly employable (Desjardins \& Rubenson, 2009; Rodrigues, Guest, \& Budjanovcanin, 2016). Due to these barriers, they might change their attributions. More specifically, those who perceive themselves as less employable may base their employability perceptions on contextual limits more than on their own talents and skills. This external attribution will affect their behavioral response (Nunez et al., 2005; Oghojafor, Olayemi, Oluwatula, \& Okonji, 2012): These individuals might be less likely to engage in work-related learning, as they believe they cannot affect their employability themselves. Similarly, if they engage in work-related learning, their perceived employability might not be affected, as they believe it is withheld by the structural barriers they encounter.

The evidence to date seems to support the idea that work-related learning contributes to success experiences in the form of the perception of being employable. Formal work-related learning promotes perceived internal employability (Nurita, Pa'Wan, Akmar Othman, \& Moksin, 2010; Sanders $\&$ de Grip, 2004), perceived external employability (Nurita et al., 2010), and more general perceptions of employability (Berntson, Sverke, \& Marklund, 2006; Carbery \& Garavan, 2005; Panagiotakopoulos, 2011). Informal learning using personal sources contributed to general perceived 
employability in the study by Panagiotakopoulos (2011). Other studies provided indirect support using indicators that are related to perceived employability, for example, perceived competences needed to be employable (e.g., Froehlich, Beausaert, \& Segers, 2015; Gerken, Beausaert, \& Segers, 2016). No studies to date concerned informal learning using environmental sources in relation to perceived employability.

Studies that test the relationship from perceived employability to work-related learning are lacking. Indirect empirical evidence comes from studies that used concepts that are conceptually related to perceived employability (e.g., career attitudes) or work-related learning (e.g., career behavior). For example, career attitudes (i.e., career motivation and orientation) were found to stimulate informal work-related learning (Sanders, Oomens, Blonk, \& Hazelzet, 2011; van Rijn, Yang, \& Sanders, 2013), and perceived employability was found to stimulate career behavior (i.e., helping behavior in the context of work; De Cuyper et al., 2014).

Accordingly, we formulate the following hypothesis: A positive and reciprocal relationship exists between perceived (internal and external) employability and work-related learning (i.e., formal workrelated learning and informal work-related learning using personal and environmental sources).

\section{Method}

\section{Procedure and Sample}

The data were collected via a Belgian International Organization for Standardization (ISO) certified marketing research company. Wage earners working in different organizations in Belgium were invited per e-mail to participate in an online survey in November 2016 (Wave 1, i.e., T1), May 2017 (Wave 2, i.e., T2), and November 2017 (Wave 3, i.e., T3). At all occasions, the respondents had 1 week to fill out the questionnaire. After the initial invitation, nonrespondents were sent two more reminders (during the first two collections) and one reminder during the last collection. Participation in the study was voluntary. To encourage continued participation, respondents could win a voucher upon completion of each survey with higher chances upon completion of all three surveys. The voucher values ranged from $€ 30$ to $€ 250$. Before participation, respondents agreed to an informed consent in which they were assured that their identities would be protected, the data would be treated confidentially, and that they could end their participation at any time.

The sample was stratified according to age and educational level. As the panel provider did not have information on the current employment status of their members, 10,291 invitations were sent with the message to only respond if in paid employment at the time. All respondents who were invited to participate at $\mathrm{T} 1$ were also invited for the following two surveys. At Time 1, 1,539 respondents started to fill out the questionnaire, of whom 1,373 provided a complete response (i.e., $89 \%$ ). Numbers at T2 are 1,748 and 1,571 (i.e., 90\%) and at T3, 1,145 and 989 (i.e., 86\%), respectively. Those who lost employment during one of the following waves were not included in the analysis.

Complete data of 462 respondents were collected. The analyses were based on data from 2,518 respondents who filled out their background characteristics and completed at least one key variable. Including incomplete data offers a more accurate estimation than complete data from a relatively small subset of the sample (Allison, 2003). Respondents' age ranged from 18 to 68 (mean $[M]=39.89$; standard deviation $[S D]=12.70$ ). Most respondents were highly educated (International Standard Classification of Education [ISCED] 5-8; bachelor degree or higher; 63\%), though a significant share was less educated (ISCED 0-4; below bachelor degree; 37\%). Most respondents were female (58\%), worked full time $(70 \%)$ in a permanent employment contract $(88 \%)$. Those who worked part time (i.e., $30 \%)$ worked on average $26 \mathrm{hr}$ per week $(S D=7.25)$. Of all respondents, $46 \%$ worked in the profit sector, $42 \%$ worked in nonprofit, and $13 \%$ in social profit. 


\section{Measures}

Perceived employability. Perceived employability was measured using the instrument developed by De Cuyper and De Witte (2008). The instrument includes two scales with good internal consistency, measuring (1) perceived internal employability $(.94<\alpha<.95$ across the three waves) and (2) perceived external employability ( $\alpha=.95$ across all waves). In a previous study, similar reliabilities were found for perceived internal $(\alpha=.92)$ and external $(\alpha=.95)$ employability (Nelissen et al., 2017). Example items are "I am confident that I could quickly get another job, within my current organization (perceived internal employability), elsewhere (perceived external employability)." Respondents rated the items on a 5-point Likert-type scale ranging from 1 (totally disagree) to 5 (totally agree). A past study showed that both perceived internal and external employability related to upward job transitions and perceived internal employability to formal on-the-job training (Nelissen et al., 2017).

Work-related learning. Work-related learning was assessed using the instrument of Grosemans, Smet, Houben, De Cuyper and Kyndt (2019), which includes an extended set of activities individuals undertake with regard to their career. The instrument consists of three scales of work-related learning displaying good internal consistency reliability as measured by Cronbach's $\alpha$ statistics: (1) formal work-related learning (.82 $<\alpha<.85$ across the three waves), (2) informal work-related learning from personal sources $(.89<\alpha<.90$ across the three waves), and (3) informal work-related learning from environmental sources $(.79<\alpha<.83$ across the three waves). In a previous study, similar reliabilities were found: Formal work-related learning $(\alpha=.81)$, informal learning from personal sources $(\alpha=$ .83 ), and informal learning from environmental sources $(\alpha=.80)$. Example items are during the last 6 months, how many times did you engage in the following activities, with regard to your (future) work: "attended a presentation" (formal work-related learning), "asked the opinion of others about what I did" (informal work-related learning from personal sources), and "payed attention to how others managed things" (informal work-related learning from environmental sources). Answers ranged on a 7-point frequency scale from $1=$ never to $7=$ on a daily basis. In a previous study, self-efficacy and work-domain goal orientation have been found to relate to work-related learning (Grosemans, Coertjens, \& Kyndt, 2018).

Control variables. As certain groups of individuals perceive more labor market boundaries, accounted for those factors that may discourage them to put in effort (i.e., work-related learning) and to perceive career opportunities (i.e., perceived employability). Research suggests that older (Berntson et al., 2006), less educated (Forrier \& Sels, 2003b) women (Andrew, 2009) report lower levels of perceived employability and engage less in work-related learning (age: De Lange et al., 2010; gender: Knipprath \& De Rick, 2014; education: Kyndt \& Baert, 2013). Age was included as a continuous variable. Educational level was dummy coded in $0=$ less educated individuals (ISCED 0-4) and $1=$ higher educated individuals (ISCED 5-8). A binary variable representing gender was also computed.

\section{Analysis Strategy and Fit Indices}

In a first part of the analyses, the measurement model was compared with alternative models, multicollinearity and nonnormality were checked, longitudinal measurement invariance was explored, and internal and external validity were investigated. In the second part of the analyses, the hypothesized model was compared with competing models, stationarity was explored, and the reciprocal relations were tested on whether they were of the same magnitudes.

Given that $\chi^{2}$ tests are sensitive to sample size (Bentler \& Bonett, 1980), we followed the recommendations of Chen (2007) to test measurement and time invariance (Preacher, 2015; Vahle-Hinz, Mauno, De Bloom, \& Kinnunen, 2017). For testing metric invariance, a change of $\geqq-.010$ in comparative fit index $(\mathrm{CFI})$, supplemented by a change of $\geqq .015$ in root mean square error of 
approximation (RMSEA) or a change of $\geqq .030$ in standardized root mean square residual (SRMR) would indicate noninvariance. For testing the other measurement invariance models, a change of $\geqq-.010$ in CFI, supplemented by a change of $\geqq .015$ in RMSEA or a change of $\geqq .010$ in SRMR would indicate noninvariance (Chen, 2007). For time invariance, the latter most strict criteria were adopted. A nonsignificant loss of fit for the more constricted models indicates that longitudinal measurement invariance and time invariance hold.

For testing the hypotheses, bootstrapping ( $\mathrm{BS}=1,000)$ with $95 \%$ confidence intervals was used, as it offers advantages over traditional approaches (Preacher \& Hayes, 2008). For evaluating model fit, CFI, RMSEA, SRMR, and Bayesian information criterion (BIC) were compared with conventional standards (i.e., CFI > .90; RMSEA < .08; SRMR < .09; Weston \& Gore, 2006). For BIC, the rule of thumb states "the smaller the value, the better the fit." For comparing models, difference $\chi^{2}$ tests were used. A significant $\chi^{2}$ difference refers to a better fit of the more complex model.

\section{Results}

\section{Establishing the Measurement Model}

First, the expected measurement model was tested against three competing models using full information maximum likelihood estimation in Mplus 8 software. The expected measurement model (MM1) with 3 factors of work-related learning and 2 factors of perceived employability in three waves (resulting in 15 factors, i.e., 5 at each wave) yielded a good fit to the data $\left(\chi^{2}=5,067.99 ; d f=1,743 ; \mathrm{CFI}=\right.$ .951 ; RMSA $=.028 ; \mathrm{SRMR}=.041 ; \mathrm{BIC}=230,134.71)$. This measurement model provided a better fit compared to three competing models: a 12-factor model (i.e., 4 factors at each wave) in which all perceived employability items loaded on the same factor (MM2), a 12-factor model (i.e., 4 factors at each wave) in which all items of informal work-related learning (from personal sources and from environmental sources) loaded on the same factor (MM3), and a 9-factor model (i.e., 3 factors at each wave) in which all work-related learning factors loaded on the same factor (MM4; see Table 1).

Second, $M \mathrm{~s}, S D \mathrm{~s}$, and correlations were computed using IBM SPSS 24.0 software (see Table 2). After rejecting multicollinearity (i.e., correlations higher than $r=.85$ ) and nonnormality (i.e., skewness index $>3$; Kurtosis index $>10$; Weston \& Gore, 2006), all further analyses were performed using Mplus 8 software and full information maximum likelihood estimation. Longitudinal measurement invariance was then tested. The 15-factor measurement model showed full measurement invariance (i.e., loadings, intercepts, item residual variances, and correlations between item residuals at adjacent waves, fixed across time), which assures that the items were interpreted in the same manner across all time waves (Selenko, Mäkikangas, \& Stride, 2017). The change in CFI, RMSEA, and SRMR (i.e., $\Delta$ CFI $=$ $-.001, \Delta \mathrm{RMSEA}=.000, \Delta \mathrm{SRMR}=.000)$ did not exceed Chen's (2007) cutoff scores (see Table 1).

Third, the average variance extracted (AVE) scores for each factor from the best fitting measurement model demonstrated internal convergent validity (the factor's AVE exceeded .5) and external discriminant validity at each wave (the AVE factor exceeded each of the squared correlations with other factors; Fornell \& Larcker, 1981), as can be seen in Table 2.

\section{Testing the Hypothesis}

The hypotheses were tested by extending the best measurement invariance model by adding the autoregressive paths, the control variables, and the hypothesized paths. The cross-lagged reciprocal paths between work-related learning and perceived employability were estimated longitudinally: From concept $\mathrm{X}$ at T1 and T2 to concept $\mathrm{Y}$ at T2 and T3, respectively. This hypothesized structural model was then compared to three competing models. In support of our hypothesis, the reciprocal model $\left(\chi^{2}=\right.$ $6,658.51 ; d f=2,070 ; \mathrm{CFI}=.933 ; \mathrm{RMSEA}=.030 ; \mathrm{SRMR}=.071 ; \mathrm{BIC}=229,056.77)$ fitted the data 

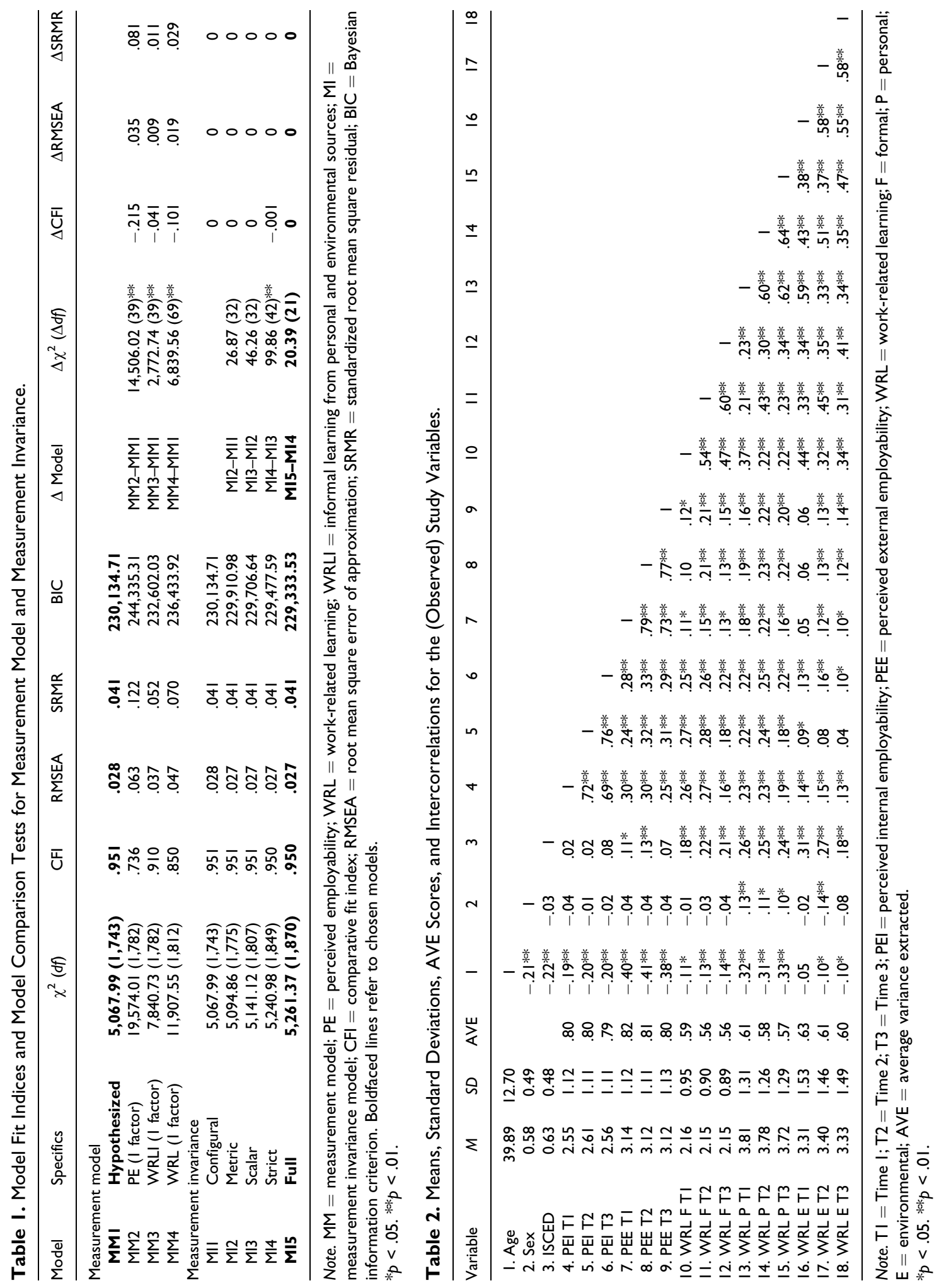
better than the model with only cross-lagged paths of work-related learning to perceived employability $\left(\Delta \chi^{2}=29.26 ; \Delta d f=12 ; p<.01\right)$ and better than the model with only cross-lagged paths of perceived employability to work-related learning $\left(\Delta \chi^{2}=23.98 ; \Delta d f=12 ; p<.05\right)$. The autoregressive model provided the poorest fit. An overview of the fit indices of all competing models can be found in Table 3.

We then assessed stationarity (i.e., the degree to which the hypothesized paths were time invariant) by testing whether equivalent paths between constructs were stable over time (Preacher, 2015). The model in which all relations were estimated freely $\left(\chi^{2}=6,658.51 ; d f=2,070 ; \mathrm{CFI}=.933\right.$; $\mathrm{RMSEA}=.030 ; \mathrm{SRMR}=.071 ; \mathrm{BIC}=229,056.77)$ was compared to a model in which equality constraints were imposed on the equivalent paths of the cross-lagged relations. As these constraints did not compromise the model, we demonstrated that the model was stationary (i.e., $\Delta \mathrm{CFI}=.000$, $\Delta$ RMSEA $=.000, \Delta$ SRMR $=.001)$.

Finally, we investigated whether the causal paths of the reciprocal effects were equal to allow a better understanding about the nature of the reciprocal relationship. We found that the time invariant model (Model A) was not compromised when compared with Model B that represented the same model but with equality constraints on all mutual paths of the reciprocal relationship $\left(\Delta \chi^{2}=\right.$ 5.78; $\Delta d f=6 ; p>.05)$. Thus, this lends further support to a reciprocal relationship, as it suggests that the significant reciprocal effects are of the same magnitudes. However, contrary to expectations, results provide only limited support for our hypothesis that a reciprocal relationship exists between work-related learning and perceived employability. Only one significant reciprocal relationship emerged: For formal work-related learning and perceived internal employability, positive paths of the same magnitude were found (for more details, see Figure 1).

\section{Discussion}

The current study set out to probe the reciprocal relationship between perceived employability and work-related learning. It is often assumed that work-related learning stimulates employability, yet (a) potential reciprocity had not yet been addressed, and (b) a broad account of both concepts was missing. We included three types of work-related learning (i.e., formal work-related learning, informal work-related learning from personal sources, and informal work-related learning from environmental sources), and perceived internal and external employability. This aim was achieved through structural equation modeling on three-wave survey data of a diverse sample of Belgian employees in terms of participants' organizational type and demographic characteristics such as age, educational level, and gender. We placed this aim against the background of the attribution-based theory of intrapersonal motivation (Weiner, 2000), which had not yet figured in employability research. Results provided evidence for a reciprocal relationship between formal work-related learning and perceived internal employability, while all other relations were insignificant. We see 3 points that deserve further comment.

First, the reciprocal relationship between formal work-related learning and perceived internal employability aligns with the attribution-based theory of intrapersonal motivation. Both formal work-related learning and perceived internal employability may trigger the attributional process (Weiner, 2000) more than informal work-related learning and perceived external employability do: Formal work-related learning provides a structured and clear image of the learning objective compared to informal work-related learning (Marsick \& Watkins, 2001). Hence, it might be easier to attribute an increase in perceived employability to formal work-related learning. Further, as most employees are more familiar with the demands and requirements in the internal labor market, changes in perceived internal employability might be easier to notice than changes in perceived external employability. Thus, the effect of formal work-related learning on perceived internal employability might be more readily observable, and thus evoke more work-related learning, which would explain the significant 


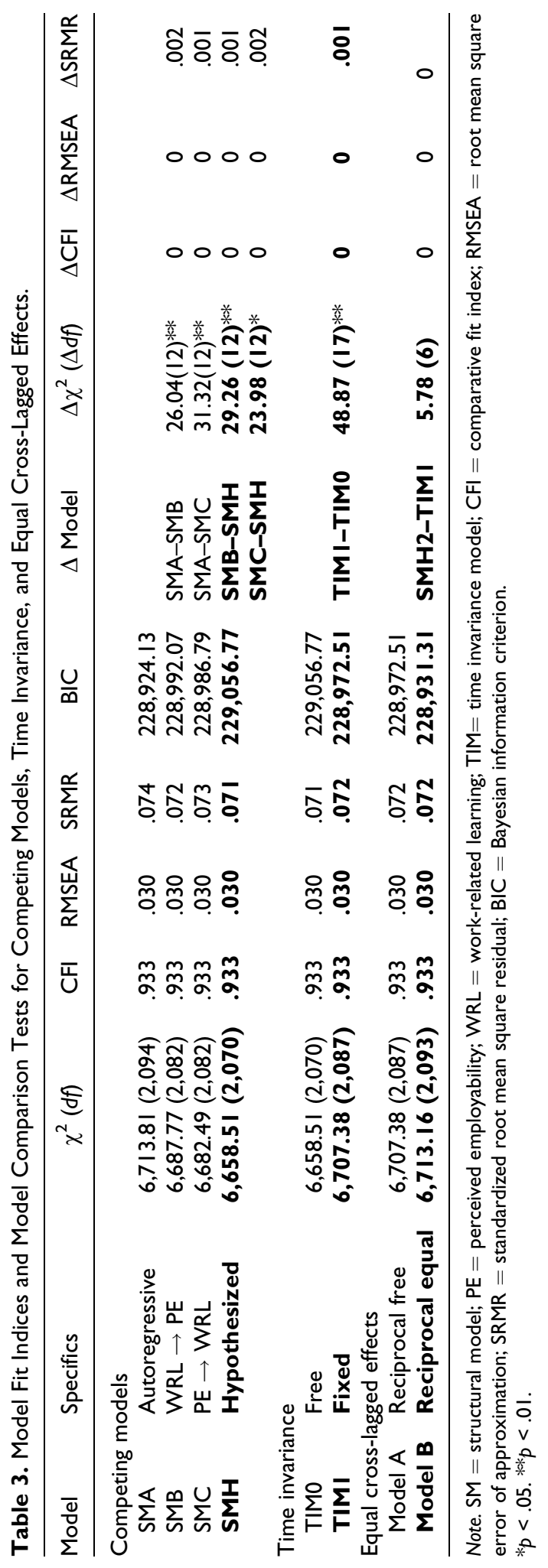




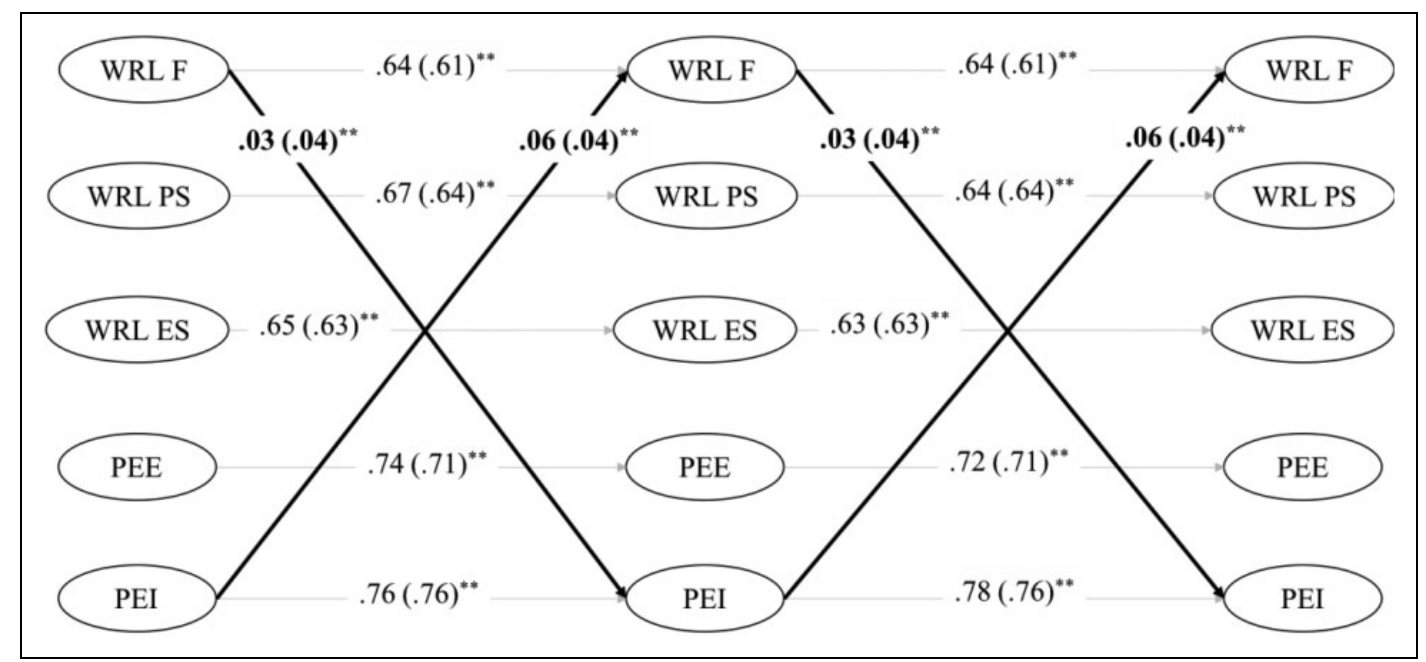

Figure I. Standardized (and unstandardized) path coefficients of the final model. Unstandardized coefficients between reciprocal and cross-lagged relations were fixed to be equal. Control variables, insignificant relations, factor indicators, and covariances are omitted for clarity. The ellipses refer to latent variables. WRL $=$ workrelated learning, $\mathrm{F}=$ formal, $\mathrm{PS}=$ personal sources, $\mathrm{ES}=$ environmental sources, $\mathrm{PEE} / \mathrm{PEI}=$ perceived external employability/perceived internal employability, $*^{*} p<.0$ I.

reciprocal relationship. The strength of this relationship is rather small, yet we believe meaningful: perceived employability is rather stable (Törnroos, Bernhard-Oettel, \& Leineweber, 2017), and hence relatively small changes could be influential. Similarly, the small influence of perceived internal employability might be rather meaningful as the engagement in formal work-related learning is quite time-consuming compared to informal learning, which may occur in any regular workday (Marsick \& Watkins, 2001). Hence, as one might easily reach a ceiling effect for formal work-related learning, it might be quite difficult to level up the engagement in this type of learning.

Second, informal learning did not relate to perceived internal and external employability. These findings might be explained by the lack of visibility of informal work-related learning for both the self (as it may occur unconsciously or unintendedly) and others (as it may be less noticeable compared to formal work-related learning), making it difficult to attribute outcomes to this type of behavior (Weiner, 2000). Lack of visibility for others is important: Employers typically prefer trainable employees (Thurow, 1972), and participation in work-related training may serve as a signal (Spence, 1973). Yet, this signal is much more visible for formal work-related learning which often brings credits than for informal work-related learning (Nelissen et al., 2017). Thus, the lack of receiving recognition (e.g., job opportunities) after their engagement in informal work-related learning may inhibit the attributions of perceived employability to these activities.

Third, both types of work-related learning did not promote perceived external employability. Although work-related learning was framed in the questionnaire as "activities undertaken with regard to (future) work," individuals might (a) have made a too narrow interpretation of this question by only focusing on the internal labor market as this might be more meaningful for most employees or (b) predominantly learn in function of their current job and/or organization. The latter is plausible when considered against the background of the attribution-based theory of intrapersonal motivation (2000): The ease of recognizing the added value of work-related learning may be more readily observable for the internal than for the external labor market. For instance, organizations mostly stimulate work-related learning for the purpose of enhancing specific task- and function-related skills (Slotte, Tynjälä, \& Hytönen, 2004). Hence, one's perceived internal employability might be more easily attributed to 
these work-related learning activities than one's external perceived employability. Following the theory, the absence of the attribution that work-related learning stimulates perceived external employability will also change their behavioral response: Perceived external employability might no longer evoke the response of engaging in work-related learning.

\section{Limitations and Suggestions for Future Research}

Even though this study was set up with great care (e.g., three-wave longitudinal design, employee participation independent from employer, establishment of time invariance), the following limitations and potential routes for future research are recognized.

First, this study demonstrated the importance of the distinction between the different types of workrelated learning and the different dimensions of perceived employability, yet an arguable weakness is the absence of specific hypotheses for each relationship. This was due to the fact that there was limited empirical evidence and no theoretical framework available accounting for the specific relations between the different types of work-related learning and employability. However, our introduction of Weiner's (2000) attribution-based theory of intrapersonal motivation in the employability literature may enhance theoretization: We could provide an intuitive explanation for the presence and absence of specific relationships (such as formal work-related learning with perceived internal employability), which we would not be able to achieve using most prominent theories in employability literature. These theories, which are loosely based on theories from other research fields (see Forrier et al., 2018, for a discussion), can only offer a general explanation for why work-related learning could enhance perceived employability (see Becker's, 1975, human capital theory) or why perceived employability could also stimulate work-related learning (see Hobfoll's concervation of resources theory, 1989). However, more research is needed to provide better guidance on whether the attribution-based theory of intrapersonal motivation (2000) would aid research on career-related behavior and perceptions and work-related learning and perceived employability in particular.

Second, we examined the reciprocal relationship between three types of work-related learning and two types of perceived employability and found a significant effect for the relation between formal work-related learning and perceived internal employability. This finding should alert future researchers to take reciprocity into account when addressing the relationship (especially when adopting a cross-sectional design). Moreover, this finding could also motivate researchers to examine potential accumulation effects for this significant and reciprocal relation using latent growth curve analyses. Accumulation implies an increasing gap over time between the higher and lower employable, as described under the heading of the Matthew effect (Forrier et al., 2018).

Third, we acknowledge that our choice to focus upon perceived employability is one out of many other options, though one that is particularly well suited for the purpose of this study. Although perceived employability is subjective in nature, previous studies have shown relationships with objective indicators of employability such as job transitions (Forrier, Verbruggen, \& De Cuyper, 2015). However, it would also benefit research to investigate the relation of work-related learning with other employability measures such as job transitions (Nelissen et al., 2017) or employability competences (e.g., Van der Heijde \& van der Heijden, 2006). Another, yet related, limitation of this study was the use of self-ratings. However, the use of a data collection which is entirely independent of respondents' organizations provided the benefit of reducing social desirability bias. Future research could supplement self-ratings with company data on work-related learning or other ratings on employability.

\section{Practical Implications}

The present study does not only have implications for employability policies (both on a governmental and organizational level) but also for career counseling. First, the relation between work-related 
learning and perceived employability seems to be rather weak. This might imply that work-related learning should be supplemented with other employability-stimulating practices, individually or via career counseling (e.g., setting career goals; Bagshaw, 1997), organizationally (e.g., transformational leadership; van der Heijden \& Bakker, 2011), and governmentally (e.g., reducing labor market barriers; Hennekam, 2015).

Second, our findings demonstrate that formal work-related learning stimulates perceived internal (but not external) employability. Accordingly, practitioners should be aware of the possibility that work-related learning solely benefits the individual's confidence in the internal labor market. On the one hand, these findings may be beneficial for organizational employability policies as concerns that supporting work-related learning would stimulate turnover due to the enhancement of perceived external employability seem to be ungrounded (Baruch, 2001; De Cuyper \& De Witte, 2012). On the other hand, these findings might be less desirable for individuals who wish to increase perceived external employability (for instance, during times of restructuring) as other employability-stimulating practices might be needed to get the desired result.

Third, we were unable to demonstrate that informal learning relates to employees' perceived employability: Accordingly, formal work-related learning should not (yet) make place for informal alternatives in view of enhancing employability perceptions. Despite the costs attached to formal work-related learning and despite the convenience of informal work-related learning (such as the current accessibility of the enormous amount of information on the Internet), it might still be important to pursue more structured ways of learning.

Fourth, organizations and career coaches should bear in mind that a cyclic relation was found between work-related learning and perceived employability. Hence, stimulating one variable might start of a self-maintaining cycle between these concepts. Following Weiner's (2000) attribution theory, career coaches may want to explore and help the employees to reappraise underlying difficulties and perceived labor market boundaries, which might affect their motivation to participate in development activities (Desjardins \& Rubenson, 2009; Meyers, 2016).

\section{Conclusion}

Returning to the question posed at the beginning of this study, our conclusion is that the relationship between work-related learning and employability might not be as straightforward as originally assumed. In the current study, (a) significant and reciprocal relationships only existed for specific forms (i.e., formal work-related learning and perceived internal employability), (b) reciprocal effects occurred with the same magnitudes, and (c) even for these significant and positive reciprocal relations, the effects were rather weak. Hence, the dominant view in the employability literature needs to be adapted: The current, highly agentic, view might be too optimistic in terms of what can be achieved by the individual, as perceived labor market barriers might hinder employability enhancement.

\section{Authors' Note}

Eva Kyndt is also affiliated with the Centre for the New Workforce, Swinburne University of Technology, Australia.

\section{Declaration of Conflicting Interests}

The author(s) declared no potential conflicts of interest with respect to the research, authorship, and/or publication of this article.

\section{Funding}

The author(s) disclosed receipt of the following financial support for the research, authorship, and/or publication of this article: This study was supported by the Research Fund KU Leuven (C24/15/008). 


\section{References}

Allison, P. D. (2003). Missing data techniques for structural equation modeling. Journal of Abnormal Psychology, 112, 545-557. doi:10.1037/0021-843X.112.4.545

Andrew, A. (2009). Challenging boundaries to 'employability': Women apprentices in a non-traditional occupation. Social Policy and Society, 8, 347-359. doi:10.1017/S1474746409004898

Atkinson, J. W. (1957). Motivational determinants of risk-taking behavior. Psychological Review, 64, 359-372. doi: $10.1037 / \mathrm{h} 0043445$

Bagshaw, M. (1997). Employability-Creating a contract of mutual investment. Industrial and Commercial Training, 29, 187-189. doi:10.1108/00197859710177468

Baruch, Y. (2001). Employability: A substitute for loyalty? Human Resource Development International, 4, 543-566. doi:10.1080/13678860010024518

Becker, G. S. (1975). Human capital: A theoretical and empirical analysis, with special reference to education. New York, NY: NBER.

Bentler, P., \& Bonett, D. (1980). Significance tests and goodness of fit in the analysis of covariance structures. Psychological Bulletin, 88, 588-606. doi:10.1037//0033-2909.88.3.588

Berntson, E., Sverke, M., \& Marklund, S. (2006). Predicting perceived employability: Human capital or labour market opportunities? Economic and Industrial Democracy, 27, 223-244. doi:10.1177/0143831X06063098

Brown, P., Hesketh, A., \& Wiliams, S. (2003). Employability in a knowledge-driven economy. Journal of Education and Work, 16, 107-126. doi:10.1080/1363908032000070648

Carbery, R., \& Garavan, T. N. (2005). Organisational restructuring and downsizing: Issues related to learning, training and employability of survivors. Journal of European Industrial Training, 29, 488-508. doi:10. $1108 / 03090590510610272$

Chen, F. F. (2007). Sensitivity of goodness of fit indexes to lack of measurement invariance. Structural Equation Modeling, 14, 464-504. doi:10.1080/10705510701301834

Colley, H., Hodkinson, P., \& Malcom, J. (2003). Informality and formality in learning: A report for the Learning and Skills Research Centre. doi:031492

De Cuyper, N., \& De Witte, H. (2008). Perceived chance of alternative employment versus better employment: Associations with job satisfaction and well-being. Gedrag En Organisatie, 21, 475-492.

De Cuyper, N., \& De Witte, H. (2012). The management paradox: Self-rated employability and organizational commitment and performance. Personnel Review, 40, 152-172. doi:10.1108/00483481111106057

De Cuyper, N., Sulea, C., Philippaers, K., Fischmann, G., Iliescu, D., \& De Witte, H. (2014). Perceived employability and performance: Moderation by felt job insecurity. Personnel Review, 43, 536-552. doi:10.1108/PR03-2013-0050

De Lange, A. H., Taris, T. W., Jansen, P., Kompier, M. A. J., Houtman, I. L. D., \& Bongers, P. M. (2010). On the relationships among work characteristics and learning-related behavior: Does age matter? Journal of Organizational Behavior, 31, 925-950. doi:10.1002/job.649

De Vries, S., Gründemann, R., \& Van Vuuren, T. (2001). Employability policy in Dutch organizations. International Journal of Human Resource Management, 12, 1193-1202. doi:10.1080/09585190110068395

Desjardins, R., \& Rubenson, K. (2009). The impact of welfare state regimes on barriers to participation in adult education: A bounded agency model. Adult Education Quarterly, 59, 187-207. doi:10.1177/074171360 9331548

European Commission. (2014). Employability and skills of higher education graduates. EU Skills Panorama. Retrieved from https://skillspanorama.cedefop.europa.eu/sites/default/files/EUSP_AH_Graduates_0.pdf

Fleischmann, M., Koster, F., \& Schippers, J. (2015). Nothing ventured, nothing gained! How and under which conditions employers provide employability-enhancing practices to their older workers. International Journal of Human Resource Management, 26, 2908-2925. doi:10.1080/09585192.2015.1004100

Fornell, C., \& Larcker, D. F. (1981). Evaluating structural equation models with unobservable variables and measurement error. Journal of Marketing Research, 18, 39-50. doi:10.1177/002224378101800104 
Forrier, A., De Cuyper, N., \& Akkermans, J. (2018). The winner takes it all, the loser has to fall: Provoking the agency perspective in employability research. Human Resource Management Journal, 28, 511-523. doi:10. $1111 / 1748-8583.12206$

Forrier, A., \& Sels, L. (2003a). The concept employability: A complex mosaic. International Journal of Human Resources Development and Management, 3, 102-124. doi:10.1504/IJHRDM.2003.002414

Forrier, A., \& Sels, L. (2003b). Temporary employment and employability: Training opportunities and efforts of temporary and permanent employees in Beligum. Work, Employment and Society, 17, 641-666. doi:10. $1177 \% 2 \mathrm{~F} 0950017003174003$

Forrier, A., Verbruggen, M., \& De Cuyper, N. (2015). Integrating different notions of employability in a dynamic chain: The relationship between job transitions, movement capital and perceived employability. Journal of Vocational Behavior, 89, 56-64. doi:10.1016/j.jvb.2015.04.007

Froehlich, D. E., Beausaert, S. A. J., \& Segers, M. S. R. (2015). Great expectations: The relationship between future time perspective, learning from others, and employability. Vocations and Learning, 8, 213-227. doi: 10.1007/s12186-015-9131-6

Gerken, M., Beausaert, S., \& Segers, M. (2016). Working on professional development of faculty staff in higher education: Investigating the relationship between social informal learning activities and employability. Human Resource Development International, 19, 135-151. doi:10.1080/13678868.2015.1116241

Goller, M., \& Harteis, C. (2017). Human agency at work: Towards a clarification and operationalisation of the concept. Agency at Work, 85-103. doi:10.1007/978-3-319-60943-0_5

Grosemans, I., Coertjens, L., \& Kyndt, E. (2018). Work-related learning in the transition from higher education to work: The role of the development of self-efficacy and achievement goals. British Journal of Educational Psychology. doi:10.1111/bjep.12258

Grosemans, I., Smet, K., Houben, E., De Cuyper, N., \& Kyndt, E. (2019). Development and validation of a measurement of work-related learning. Manuscript Submitted for Publication.

Hennekam, S. (2015). Employability of older workers in the Netherlands: Antecedents and consequences. International Journal of Manpower, 36, 931-946. doi:10.1108/IJM-12-2013-0289

Hobfoll, S. E. (1989). Conservation of resources: A new attempt at conceptualizing stress. American Psychologist, $44,513$.

Katz, D., \& Kahn, R. (1978). The taking of organizational roles. In The social psychology of organizations (pp. 186-221). New York, NY: John Wiley.

Kelley, H. H., \& Michela, J. L. (1980). Attribution theory and research. Annual Review of Psychology, 31, 457-501. doi:10.1146/annurev.ps.31.020180.002325

Knipprath, H., \& De Rick, K. (2014). The economic benefits of adult learning to low-qualified young adults: Do participation and qualification decrease the risk of unemployment? Vocations and Learning, 7, 101-120. doi: 10.1007/s12186-013-9108-2

Kyndt, E., \& Baert, H. (2013). Antecedents of employees' involvement in work-related learning. Review of Educational Research, 83, 273-313. doi:10.3102/0034654313478021

Kyndt, E., Onghena, P., Smet, K., \& Dochy, F. (2014). Employees' willingness to participate in work-related learning: a multilevel analysis of employees' learning intentions. International Journal for Educational and Vocational Guidance, 14, 309-327. doi:10.1007/s10775-014-9272-4

Marsick, V. J., \& Watkins, K. E. (2001). Informal and incidental learning. In New directions for adult and continuing education (pp. 25-34). doi:10.1002/ace.5

Meyers, R. (2016). Disadvantaged older jobseekers and the concept of bounded agency. International Journal of Lifelong Education, 36, 292-307. doi:10.1080/02601370.2016.1241310

Nelissen, J., Forrier, A., \& Verbruggen, M. (2017). Employee development and voluntary turnover: Testing the employability paradox. Human Resource Management Journal, 27, 152-168. doi:10.1111/1748-8583.12136

Nishii, L. H., Lepak, D. P., \& Schneider, B. (2008). Employee attributions of the 'why' of HR practices: Their effects on employee attitudes and behaviors, and customer satisfaction. Personnel Psychology, 61, 503-545. doi:10.1111/j.1744-6570.2008.00121.x 
Noe, R. A., Tews, M. J., \& Marand, A. D. (2013). Individual differences and informal learning in the workplace. Journal of Vocational Behavior, 83, 327-335. doi:10.1016/j.jvb.2013.06.009

Nunez, J. C., Gonzalez-Pienda, J. A., Gonzalez-Pumariega, S., Roces, C., Alvarez, L., Gonzalez, P., ... Rodriguez, S. (2005). Subgroups of attributional profiles in students with learning difficulties and their relation to self-concept and academic goals. Learning Disabilities Research and Practice, 20, 86-97. doi:10.1111/j. 1540-5826.2005.00124.x

Nurita, J., Pa'Wan, F., Akmar Othman, N., \& Moksin, H. (2010). Factors influencing internal and external employability of employees. Business and Economics Journal, 2010, 1-11.

Oghojafor, B., Olayemi, O., Oluwatula, O., \& Okonji, P. (2012). Attribution theory and strategic decisions on organizational success factors. Journal of Management and Strategy, 3. doi:10.5430/jms.v3n1p32

Organisation for Economic Co-operation and Development. (2016). Enhancing employability. Report prepared for the G20 Employment Working Group. Retrieved from https://www.oecd.org/g20/topics/employment-a nd-social-policy/Enhancing-Employability-G20-Report-2016.pdf

Panagiotakopoulos, A. (2011). Workplace learning and its organizational benefits for small enterprises. The Learning Organization, 18, 350-360. doi:10.1108/09696471111151701

Preacher, K. J. (2015). Advances in mediation analysis: A survey and synthesis of new developments. Annual Review of Psychology, 66, 825-852. doi:10.1146/annurev-psych-010814-015258

Preacher, K. J., \& Hayes, A. F. (2008). Asymptotic and resampling strategies for assessing and comparing indirect effects in multiple mediator models. Behavior Research Methods, 40, 879-891. doi:10.3758/BRM.40.3.879

Rodrigues, R., Guest, D., \& Budjanovcanin, A. (2016). Bounded or boundaryless? An empirical investigation of career boundaries and boundary crossing. Work, Employment and Society, 30, 669-686. doi:10. $1177 / 0950017015570726$

Sanders, J., \& de Grip, A. (2004). Training, task flexibility and the employability of low-skilled workers. International Journal of Manpower, 25, 73-89. doi:10.1108/01437720410525009

Sanders, J., Oomens, S., Blonk, R. W. B., \& Hazelzet, A. (2011). Explaining lower educated workers' training intentions. Journal of Workplace Learning, 23, 402-416. doi:10.1108/13665621111154412

Selenko, E., Mäkikangas, A., \& Stride, C. B. (2017). Does job insecurity threaten who you are? Introducing a social identity perspective to explain well-being and performance consequences of job insecurity. Journal of Organizational Behavior, 38, 856-875. doi:10.1002/job.2172

Slotte, V., Tynjälä, P., \& Hytönen, T. (2004). How do HRD practitioners describe learning at work? Human Resource Development International, 7, 481-499. doi:10.1080/1367886042000245978

Spence, M. (1973). Job market signaling. The Quarterly Journal of Economics, 87, 355-374.

Thurow, L. C. (1972). Education and economic equality. The Public Interest, 28, 66-81. doi:10.1016/j.ejmech. 2008.08.013

Törnroos, K., Bernhard-Oettel, C., \& Leineweber, C. (2017). Perceived employability trajectories: A Swedish cohort study. Journal of Occupational Health, 59, 336-344. doi:10.1539/joh.16-0295-OA

Vahle-Hinz, T., Mauno, S., De Bloom, J., \& Kinnunen, U. (2017). Rumination for innovation? Analysing the longitudinal effects of work-related rumination on creativity at work and off-job recovery. Work and Stress, 31, 315-337. doi:10.1080/02678373.2017.1303761

Van der Heijde, C., \& van der Heijden, B. (2006). A competence-based and multidimensional operationalization and measurement of employability. Human Resource Management, 45, 449-476. doi:10.1002/hrm.20119

van der Heijden, B., \& Bakker, A. B. (2011). Toward a mediation model of employability enhancement: A study of employee-supervisor pairs in the building sector. The Career Development Quarterly, 59, 232-248. doi:10. 1002/j.2161-0045.2011.tb00066.x

van Rijn, M. B., Yang, H., \& Sanders, K. (2013). Understanding employees' informal workplace learning. Career Development International, 18, 610-628. doi:10.1108/CDI-12-2012-0124

Vanhercke, D., Kirves, K., De Cuyper, N., Verbruggen, M., Forrier, A., \& De Witte, H. (2015). Perceived employability and psychological functioning framed by gain and loss cycles. Career Development International, 20, 179-198. doi:10.1108/CDI-12-2014-0160 
Veld, M., Semeijn, J., \& Vuuren, T. V. (2015). Enhancing perceived employability. Personnel Review, 44, 866-882. doi:10.1108/PR-05-2014-0100

Weiner, B. (1976). An attributional approach for educational psychology. Review of Research in Education, 4, 179. doi:10.2307/1167116

Weiner, B. (1985). An attributional theory of motivation and emotion. Psychological Review, 92, 548-573. doi: $10.1037 / 0033-295 \mathrm{X} / 85 / \$ 00.75$

Weiner, B. (2000). Intrapersonal and interpersonal theories of motivation from an attribution perspective. Educational Psychology Review, 12, 17-18. doi:10.1023/A:1009017532121

Weston, R., \& Gore, P. A. (2006). A brief guide to structural equation modeling. The Counseling Psychologist, 34, 719-751. doi:10.1177/0011000006286345

\section{Author Biographies}

Ellen Houben is a $\mathrm{PhD}$ candidate at the Research Group for Occupational and Organizational Psychology and Professional Learning (O2L), Faculty of Psychology and Educational Sciences, KU Leuven, Leuven, Belgium. Her research interests include individuals' career development and organizations' career management, with a specific focus on employability- and work-related learning. She was involved in several courses such as project-based education, personnel psychology, group dynamics, and the daily guidance of master theses. She enjoys beautiful nature, delicious and healthy food, spending time with family, friends, and animals (especially dogs).

Nele De Cuyper is an associate professor at the Research Group for Work, Organizational and Personnel Psychology, Faculty of Psychology and Educational Sciences, KU Leuven, Leuven, Belgium. Her research interests include employability in relation to employee well-being, attitudes, and behavior and with a focus upon precarious groups. She has published her work in international peer-reviewed journals including Journal of Organizational Behavior, Journal of Vocational Behavior, Journal of Occupational and Organizational Behavior, and the European Journal of Work and Organizational Psychology. She teaches topic in the broader area of human resource management and development.

Eva Kyndt (PhD Educational Sciences) is an associate professor in human resource development and management at the Department for Training and Education Sciences (University of Antwerp, Antwerp, Belgium) and Centre for the New Workforce (Swinburne University of Technology, Melbourne, Australia). The common thread in her research is the intersection between learning and working. More specifically, her expertise is situated in the area of workplace learning, transfer of training, social networks in organizations, and the transition from education to work. During her leisure time, she enjoys hiking, skiing, and playing the clarinet.

Anneleen Forrier ( $\mathrm{PhD}$ in Business Economics) is a full professor at the Faculty of Economics and Business of the KU Leuven, Leuven, Belgium, where she is a member of the Research Group of Work and and Organisation Studies. Her research interests include employability, careers, (re)employment, and aging policies. She teaches courses on career development, labor market issues, and HRM. She loves traveling, theater, and occasionally also engages in sports (badminton, yoga, and running). 